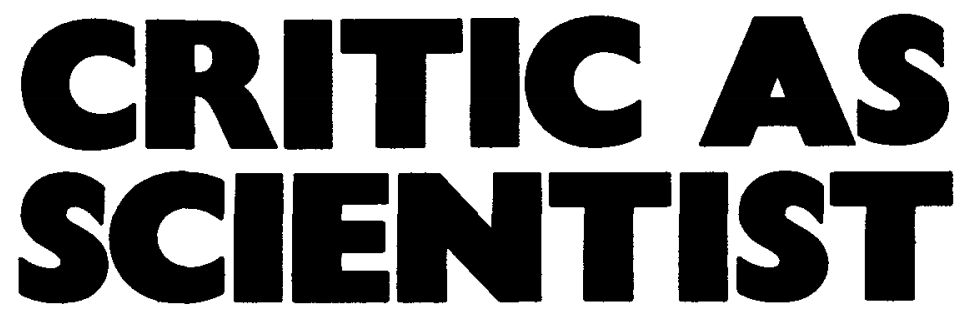

The modernist poetics of Ezra Pound IAN F A BELL

\section{Mary Chesnut's Civil} War

\section{Edited by C. Vann Woodward}

The incomparable American Civil War diarist Mary Chesnut was a witness to the life and death of the Confederacy. With intelligence and passion she described the turbulent events of politics and war, as well as the multilayered strata of society around her. The Chesnut Journals now appear in their first full and reliable edition. $£ 18.80$

\section{Desert Immigrants}

The Mexicans of El Paso, r8801920

\section{Mario T. García}

Garcia explores the relationship of class, race, and labour in El Paso, Texas, documenting the evolution of the Mexican community there. $\$ 14.50$
The Yale Gertrude Stein

\section{Selections}

with an introduction by

Richard Kostelanetz.

This distinguished anthology from the Yale Edition of the Unpublished Writings of Gertrude Stein contains some of the most extraordinary works of a writer who, a generation after her death, remains truly contemporary.

Cloth £. 8.90. Paper £4.40

\section{Matthew Josephson, Bourgeois Bohemian David E. Shi}

In this incisive and thoughtful biography, Shi uses Josephson's colourful career at the centre of many of the major cultural and intellectual events of the twentieth century, to examine the role of the leftist intellectual in American letters. Fortbcoming $£ 12.60$ 


\section{Crisis in the Making}

The Political Economy of New York State

\section{PETER D. MCCLELLAND and ALAN L. MAGDOVITZ}

This book examines the fiscal and economic crisis in New York City and State. The authors demonstrate that the crisis was as much the result of political manoeuvering as it was the outcome of long-term economic trends and fiscal ineptitude and they conclude that its causes will not be resolved until the government structure is thoroughly overhauled.

Studies in Economic History and Policy: The United States in the Twentieth Century

\section{Police in Urban America, 1860-1920 ERIC H. MONKKONEN}

The author examines the spread of uniformed police forces throughout late nineteenth-century America, showing how they initially served as agents of both criminal and class control, acquiring a functional speciality only as welfare services developed.

£16.00 net

Interdisciplinary Perspectives on Modern History

\section{Cradle of the Middle Class}

The Family in Oneida County, New York, 1780-1865 MARY P. RYAN

An examination of the emergence in the early nineteenth century of the middle-class family with its sharp division of male and female roles. The analysis sheds light on the developing social structure of a frontier area whose major village became first a commercial boom town and then a manufacturing centre.

$£ 19.50$ net

Interdisciplinary Perspectives on Modern History

\section{Language in the USA}

\section{Edited by CHARLESA. FERGUSON and SHIRLEY BRICE HEATH}

This volume considers the history, varieties and current status of the languages of the USA. The four main parts deal with American English; the languages before English; the immigrant languages; and the use of language in such contexts as law, medicine, religion and education.

Hard covers $₹ 30.00$ net Paperback ₹12.50 net 
Announcing a major new microfiche collection:

\section{PRE-1900 CANADIANA}

The most comprehensive collection ever assembled of research materials on Canada.

50,000 monographs and pamphlets printed before 1900, now being microfilmed by the Canadian Institute for Historical Microreproduction (CIHM).

Five-year publication plan, beginning with units 1 and 2 in late 1981.

Subject sections covering literature, history, politics, colonialism, etc will be made available separately.

For further details, fill in and return the coupon below to:

\section{University}

Microfilms (Exclusive distributors outside Canada)

International 30-32 Mortimer Street, London WIN 7RA, England

Please send further details of PRE-1900 CANADIANA.

I am interested in the following sub- Name

ject areas:

Address 


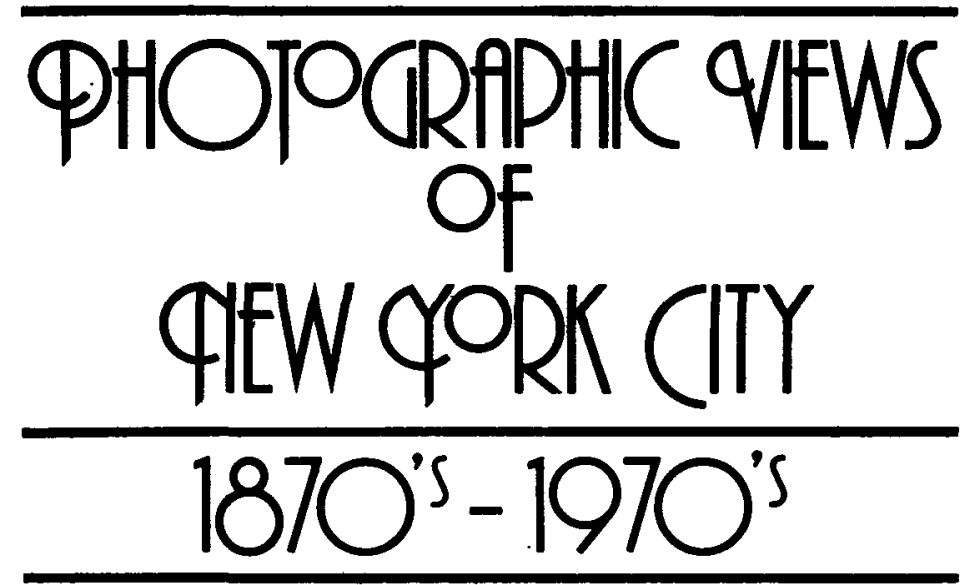

FROM THE NEW YORK PUBLIC LIBRARY

54,000 photographs of skyscrapers and street scenes, people and parades, now available as a microfiche collection.

Indexed three ways - by street, by building and by subject for easy access.

Published by UMI on 1481 fiches, price US $\$ 4,370.00$ including the three hard-copy indexes.

For more details, send the coupon below to:

\section{University}

Microfilms

International 30-32 Mortimer Street, London W1 7 7RA

TO: John Hodder, Project Manager, UMI, 30-32 Mortimer Street, London WIN 7RA

Please send more details of the microfiche collection:

PHOTOGRAPHIC VIEWS OF NEW YORK CITY

Name

Address. 
I All contributions and editorial correspondence should be sent to: The Editor, Journal of American Studies, School of English and American Studies, University of East Anglia, Norwich NR4 7 TJ, England.

2 Articles should generally contain about 5,000 words. Longer or shorter articles, or articles in two or more parts, may be accepted by arrangement with the Editors.

3 Submission of an article is taken to imply that it has not previously been published, and is not being considered for publication elsewhere.

4 Contributions should be clearly typed in double spacing (including footnotes), preferably on $\mathrm{A}_{4}$ paper, with a wide left-hand margin. Diagrams, maps and illustrations may be included.

5 Spelling may conform either to British or American usage, providing it is consistent throughout.

6 Footnotes should be used sparingly: in general, to give sources of direct quotations, references to main authorities on disputable questions, and evidence relied on for a new or unusual conclusion. They should be numbered consecutively, and may most conveniently be placed, in double spacing, at the end of the article.

7 For guidance on matters of style, contributors should refer either to the MLA Handbook (1977), or to the Journal of American Studies Style Notes, copies of which may be obtained from the Editors.

8 Contributors should keep one copy of the typescript for correcting proofs.

9 Notes intended for the Editors or Printer should be on a separate sheet.

Io First proofs may be read and corrected by contributors provided that they can give the Editor an address through which they can be reached without delay and can guarantee to return the corrected proofs to the Editor, by airmail where necessary, within three days of receiving them.

I I Corrections should be kept to an absolute minimum. They should be confined to errors of the typist or printer unless the Editor authorizes otherwise.

12 Contributors of articles and review essays receive 25 free offprints. Extra copies may be ordered according to a sfale of charges.

13 Contributors need not be members of the British Association for American Studies. Unsolicited typescripts can only be returned to overseas contributors who send International Reply Coupons (not postage stamps).

I4 Contributors of accepted articles will be asked to assign their copyright, on certain conditions, to Cambridge University Press, to help protect their material, particularly in the USA. 


\section{Journal of \\ American Studies}

Charles A. Beard: The English Experience

JOHN BRAEMAN

William Howard Russell and the Confederacy

MARTIN CRAWFORD

Local Government, Suburban Segregation and Litigation in US Metropolitan Areas

R. J. JOHNSTON

Bellow's 'Indian Givers': Humboldt's Gift

JUDIE NEWMAN

Review Essay

Faulkner's Lives

M. GIDLEY

\section{Comment}

The Frontier of Genre: Further to John S. Whitley's 'Stirring Things Up: Dashiell Hammett's Continental Op'

DAVID GLOVER

Reviews

(C) Cambridge University Press 1981

Cambridge University Press

The Pitt Building, Trumpington Street, Cambridge $\mathrm{CB}_{2}$ IRP 32 East 57th Street, New York, NY 10022

Printed in Great Britain by Western Printing Services Ltd, Bristol 